\title{
SEAGRASS RESOURCE ASSESSMENT IN THE MANDAPAM COAST OF THE GULF OF MANNAR BIOSPHERE RESERVE, INDIA
}

\author{
T. THANGARADJOU - R. SRIDHAR - S. SENTHILKUMAR - S. KANNAN \\ Centre of Advanced Study in Marine Biology Annamalai University, \\ Parangipettai - 608502 Tamil Nadu, India \\ (phone: +91-04144-243070/243071(Ext. 204), fax: +91-04144-243999) \\ e-mail: umaradjou@yahoo.com \\ (Received $28^{\text {th }}$ February 2006; accepted $23^{\text {th }}$ August 2007)
}

\begin{abstract}
Aerial extent and distribution pattern of seagrass meadows in the Mandapam group of islands viz. Pamban area of Rameshwaram, Krusadai, Pullivasal and Pumarichan Island of the Gulf of Mannar Biosphere Reserve were studied. Visual interpretation and digital analysis of satellite data viz. IRS 1D LISS III (2000 and 2002) and IRS P6 LISS III (2004) showed the presence of extensive seagrass beds in these areas. Present study has recorded 3289.14 ha of reef area, 794.45 ha of reef vegetation, 726.15 ha of dense and 601.00 ha of sparse seagrass beds in this part of the Gulf during the year 2004. Further, spread and changes in seagrass cover in this region have been classified and loss has been estimated. In addition, drastic reduction in the seagrass resources of the Gulf of Mannar in certain places was identified and management plans to conserve this resource have been suggested.
\end{abstract}

Keyword: seagrass, assessment, remote sensing, anthropogenic

\section{Introduction}

Seagrasses represent one of the important and highly productive ecosystems of the world, which supports a variety of life forms ranging from microbes to marine mammals like dugongs. Distribution of 14 species of seagrasses along the Indian coast has been reported of which 13 species occur in the Gulf of Mannar [20]. Seagrasses along with the coral reefs make this region highly productive $\left(7 \mathrm{~g} \mathrm{C} \mathrm{m}^{-2} \mathrm{~d}^{-1}\right)$ which is evident from the fact that this region yields about $5000-7000$ tons of dry seaweeds and 102,900 tons of fish annually [5].

Remote sensing and GIS techniques have been used widely in mapping and monitoring the coral reefs and mangroves throughout the world but only very less importance has been given for assessing the equally important seagrass resources, though high resolution data products are now available for identifying and delineating the seagrasses as separate entities from the coral reefs. Density of seagrasses as well as their detailed mapping can be done effectively using IRS IC/ID LISS III and pan merged data products [13].

\section{Review of literature}

Seagrass cover estimations have been attempted world wide. Exposed and submerged seagrasses beds of the Florida Bay have been categorized and differentiated using Landsat TM, SPOT XS and Airborne MSS [17]. It is suggested that the Enhanced Thematic Mapper and the High Resolution Multispectral Stereo Imager along with other technological advancements will yield data with a much higher resolution for seagrass 
mapping and studying distribution [7]. Spectral characteristics of Landsat TM bands 1, 2 and 3 over the identified seagrass area in the South China Sea have been studied [8] and found that band ratio of 2 and 1 would give a better high dense and low dense seagrass distribution patterns than the band ratio of 3 and 1 .

In India, IRS LISS II and Landsat TM data (1:50,000) were used for mapping wetlands and shoreline changes of Kavaratti and Agatti islands and classified the wetlands into different categories like beach, coral reef, algae, seagrass, beach vegetation etc. [15]. Seagrass meadows of Lakshadweep were mapped by using black and white aerial photographs [10] and IRS data [4]. IRS IC LISS III data was used to discriminate seagrass/seaweed beds separately, reef flat and sandy cay on a coral pinnacle of north-northeast of Okha in the Gulf of Kachchh [16].

From the foregoing account, it can be seen that even after the availability of high resolution data products, there are no specific studies on mapping of seagrass resources using remote sensing techniques. To fill up this lacuna, the present attempt was made to map the seagrass resources of the islands and Mandapam coast of the Gulf of Mannar Marine Biosphere Reserve.

\section{Materials and methods}

\section{Study area}

The Gulf of Mannar Marine Biosphere Reserve is the first of its kind in India and also in the south east Asia, spreading from the Pamban island (Rameshwaram) to Tuticorin in the Bay of Bengal (latitudes $8^{0} 31^{\prime}-9^{0} 25^{\prime} \mathrm{N}$ and longitudes $78^{0} 08^{\prime}-29^{0}$ 30 ' E). This Gulf is known for its coral and seagrass resources distributed along the archipelago of 21 islands with an average land area of 623.12 ha. For the present investigation, seven islands viz. Shinge, Krusadai, Pullivasal, Poomarichan, Manoliputti, Manoli and Hare islands and Pamban coast of the Rameshwaram island (Figure 1) were studied for quantifying the seagrass resources.

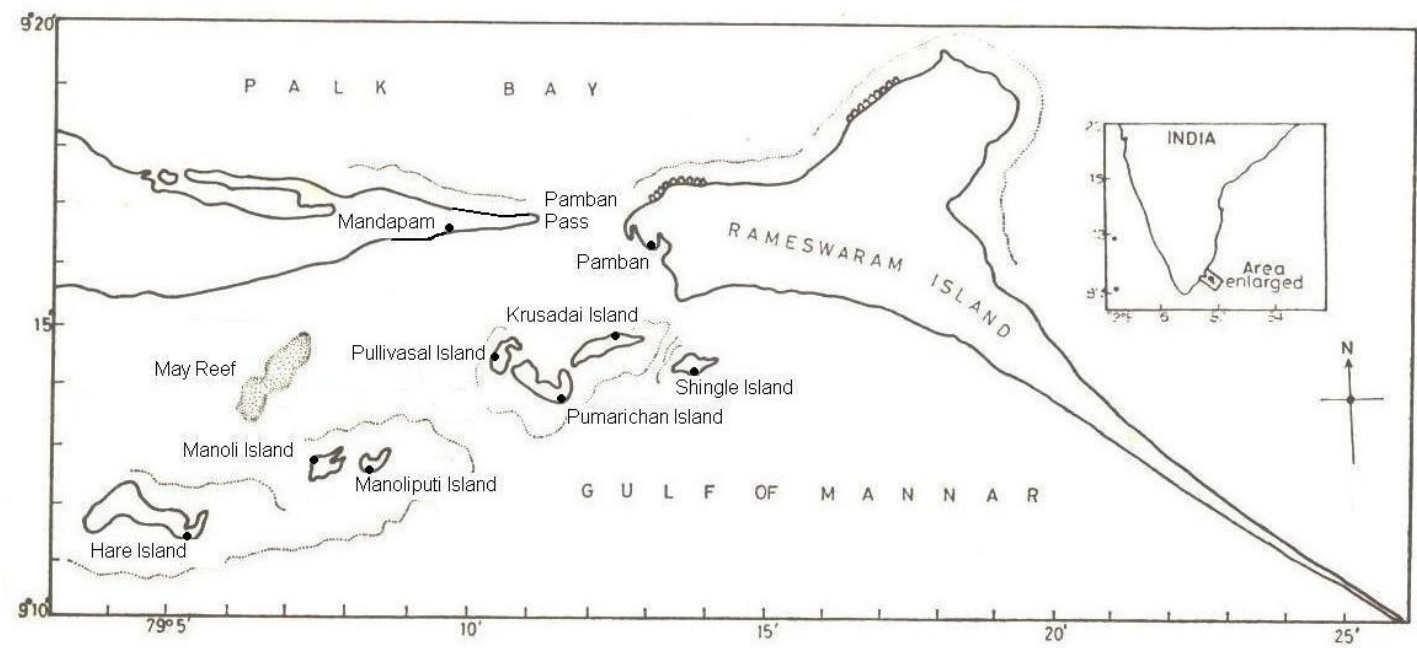

Figure 1. Map showing the study areas. 


\section{Remote sensing}

IRS LISS III satellite data products of $13^{\text {th }}$ May 2000 and $12^{\text {th }}$ January 2004 were used for the present study and $8^{\text {th }}$ May 2002 data were also used for verification. Digital data were first rectified radiometrically and corrected geometrically using the Survey of India topo sheets (No: $58 \mathrm{O} / 3 \mathrm{SE} \& \mathrm{O} / 4 \mathrm{NE}$ ), taking sufficient ground control points (GCPs). Care was taken to get data obtained during low tide regimes which would provide with more clarity in delineating low density and high density seagrass beds. False Color Composite (FCC) was generated with the band combinations 3,2,1 in RGB. Digital analysis and visual interpretation techniques were carried out using ERDAS ver. 8.6 software [13] with some modifications in the visual interpretation keys. Water column corrections were also made to carry out further classification. The classification system developed by the Space Application Centre [2] was used for resource mapping. The mapping accuracy was estimated based on sample basis, assuming a binomial distribution for the probability of success / failure of sample tests [14]. Out of the 120 sample points surveyed for the accuracy testing, 107 points have correctly matched with the maps generated during the present study with an accuracy of $87.5 \%$.

\section{Results and discussion}

\section{Coral reefs and reef vegetation}

The resource maps generaged for the Mandapam group of islands are given in Figures 2 and 3 and areal extent of various resources are given in (Table 1). The reef area of this region was estimated as 3289.14 ha and reef vegetation, composed largely of seaweeds, has been recorded as 794.45 ha during the year 2004. These estimated areas appear to be very low when compared to the earlier report [9] with over $40.5 \mathrm{~km}^{2}$ of reef area from these islands. However, if we add the reef area and reef vegetation recorded during the present study, we could get 4083.59 ha i.e. about $40.83 \mathrm{~km}^{2}$ of reef area.

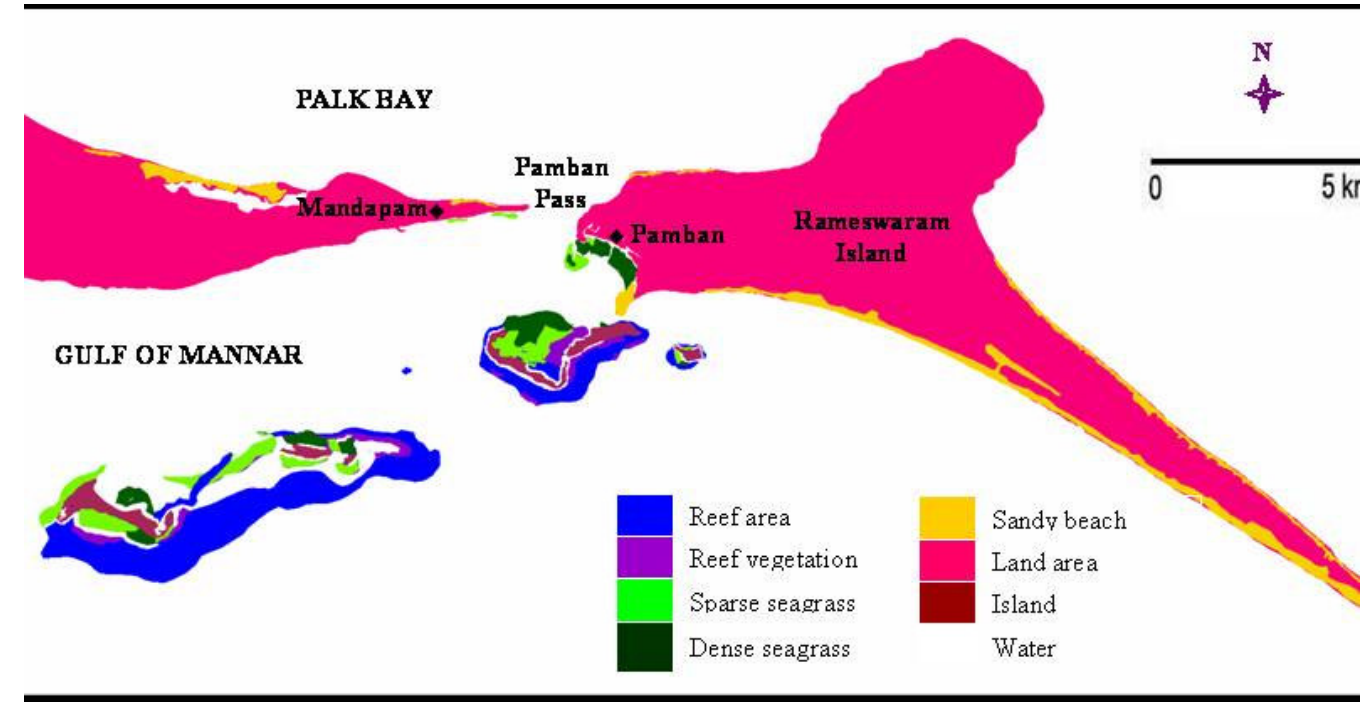

Figure 2. . Classified resource map of islands and Mandapam coast of the Gulf of Mannar derived from IRS LISS-III satellite data retrieved during 2000. 


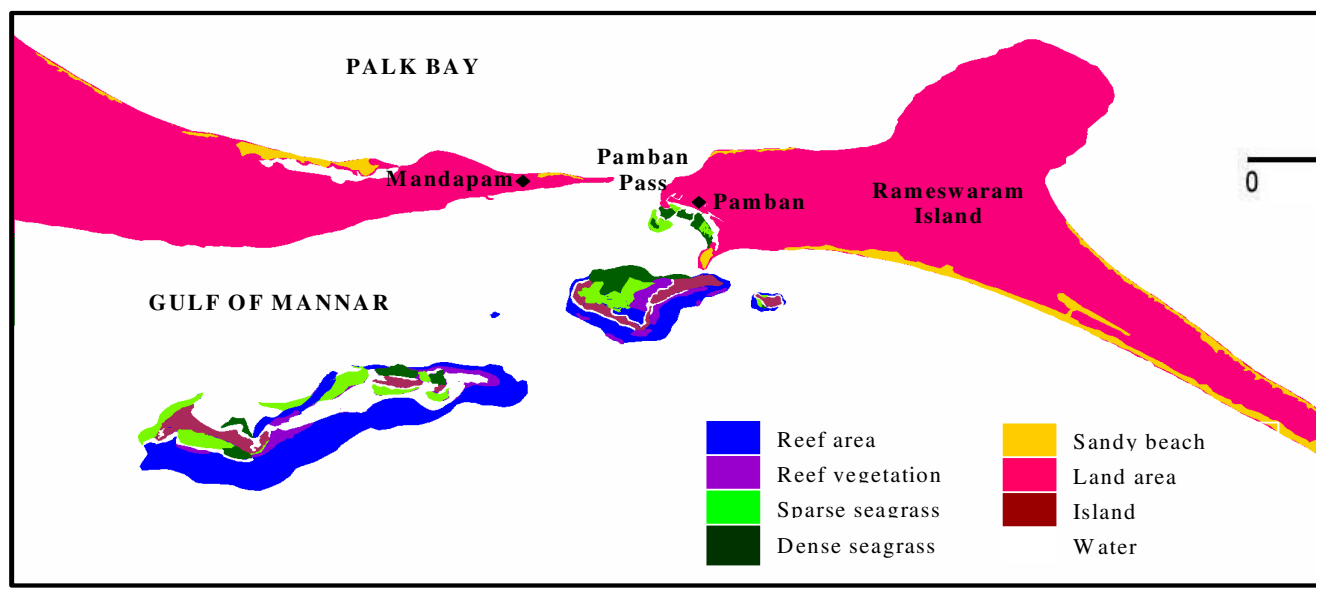

Figure 3. Classified resource map of islands and Mandapam coast of the Gulf of Mannar derived from IRS LISS-III satellite data retrieved during 2004.

Table 1. Areal extent of various resources recorded during the present study.

\begin{tabular}{c|cc|c|c}
\hline Category & \multicolumn{2}{|c|}{ Area in ha } & $\begin{array}{c}\text { Difference in Area } \\
\text { during 2000 - 2004 }\end{array}$ & $\begin{array}{c}\text { Percentage reduction } \\
\text { / addition }\end{array}$ \\
\hline Reef area & 3449.79 & 3289.14 & $(-) 160.65$ & 4.65 \\
Reef vegetation & 655.13 & 794.45 & $(+) 139.32$ & 17.53 \\
Dense seagrass & 884.97 & 726.15 & $(-) 158.82$ & 17.94 \\
Sparse seagrass & 971.54 & 601.00 & $(-) 370.54$ & 38.14 \\
\hline
\end{tabular}

Table 1 shows that there is a reduction in reef area of about 160.65 ha between 2000 and 2004. This reduction could be attributed to several anthropogenic pressures especially trap fishing in the reef areas. Moreover, an additional 139.32 ha of reef vegetation was also noticed during the same period. This indicates that the seaweeds would have gradually occupied the reef area. Such an increase in seaweeds and the need for their regular harvesting from the live coral areas for saving the corals from degradation have been discussed well [19]. Expansion of seaweed growth in the reef ecosystem would lead to reef degradation and make a phase shift from coral dominated to algal dominated and / or coral depleted area [6].

\section{Seagrass resources}

Present study has recorded 726.15 ha of dense and 601.00 ha of sparse seagrass beds in this part of the Gulf during the year 2004, accounting for a total of 1327.15 ha of seagrass beds, which figure is very low when compared to the estimate of $22.71 \mathrm{~km}^{2}$ of seagrass beds reported earlier[9]. However, the difference is less when compared to the 2000 estimate of 1856.51 ha. Entire Palk Bay and Gulf of Mannar could be expected to have a seagrass cover of ca $30 \mathrm{~km}^{2}$ [11]. But this looks very low as we have recorded about $13.25 \mathrm{~km}^{2}$ of seagrass cover only from the Mandapam group of islands alone and the seagrass cover can be high if we add that the Palk Bay and other islands of the Gulf of Mannar.

In the present study, seagrass beds have been broadly classified into two classes, viz. sparse and dense beds. The above ground biomass of the sparse and dense seagrass beds was calculated in the field. From this, the areas with the above ground biomass of $200-$ 
$500 \mathrm{~g}$ fr. wt. $\mathrm{m}^{2}$ were recorded as sparse seagrass beds while the areas with more than $500 \mathrm{~g}$ fr. wt. $\mathrm{m}^{2}$ of above ground biomass were recorded as dense seagrass beds. Areas with the above ground biomass of less than $200 \mathrm{~g}$ fr. wt. $\mathrm{m}^{2}$ could not be recorded due to spectral confusions caused by the barren sea floor and overlying waters. Another important factor to be considered here is the smaller size of some of the seagrass species Halophila spp. and Halodule spp. which could not form dense beds singly as that of the other species. Whereas, species of Enhalus acoroides, Thalassia etc. were large enough to make dense beds. Further, most of the extensive seagrass beds will be constituted by more than one species rather than a single species. These factors cause difficulties in attempting species level identifications of seagrasses using remote sensing techniques [12].

Another interesting fact recorded during the present study was the similarity of tones of coral reef, reef vegetation and seagrasses (Table 2). This would have made it difficult to map the seagrass resources as a separate entity by several workers $[21,22,3]$ and they have included seagrasses within the reef vegetation class. As the difference in tone is very narrow, it needs detailed field verifications to delineate the seagrasses in the reef area. It is worth mentioning here that the seagrass habitats are prone to spectral confusions with coral reefs, algae and deep water [1].

Table 2. Interpretation key for delineating seagrasses and other coastal resources.

\begin{tabular}{|c|c|c|c|}
\hline Category & Tone & Texture & Reference \\
\hline Coral reefs & $\begin{array}{c}\text { Greenish black / Turquoise } \\
\text { blue / blue }\end{array}$ & Smooth & Bahuguna and Nayak, 1998 \\
\hline Reef vegetation & Brownish orange & Smooth & Bahuguna and Nayak, 1998 \\
\hline Algae /seaweeds & Pinkish red & Smooth & Bahuguna and Nayak, 1998 \\
\hline Seagrasses & Orange / orangish pink & Smooth & Nayak and Bahuguna, 2001 \\
\hline Dense seagrass & Rose / orange to light red & Smooth & Present study \\
\hline Sparse seagrass & Orangish red to reddish brown & Smooth & Present study \\
\hline
\end{tabular}

More importantly the substratum which favours seagrass growth is dominated by the coarse sand and shell/coral debris. Presence of higher percentage of stone and gravel and sand fractions in the seagrass beds of the Gulf of Mannar have also been reported earlier [23]. This coarse sand with coral debris gives more or less similar reflectance as that of corals. This confusion in spectral characteristics would lead to the misidentification of seagrass areas as coral reef areas and reef vegetation, thereby resulting in erroneous calculation. It is opinioned [13] that density as well as detailed seagrass mapping can be possible using LISS III and pan merged data, but in the present study we have delineated dense and sparse seagrasses by using LISS III data alone.

\section{Conservation and management}

Chinnapalam is a small fishing village in the coast of Pamban, situated on the southern side of the island with a population of over 700 people. All are solely dependent on fishing for their livelihood and the women are engaged in selling fishes, dry fish making, seaweed collection and more importantly ornamental shells collection. More than 150 mechanized and 70 non-mechanized fishing boats are in operation from here by the fishermen and all of them are anchored on the seagrass meadows of the Chinnapalam area. Fishing boats which are operated in the nearby Palk Bay region are also anchored in the Chinnapalam area during the northeast monsoon season to avoid damages caused by heavy winds and seasonal storms [18]. Thus, the seagrass meadows 
of Chinnapalam area are highly disturbed due to human interference, fishing and anchoring of boats on the seagrass beds, oil spills, disposal of huge solid wastes and sewage. All these factors lead to the gradual reduction of seagrass resources of this region.

Though it is reported that there is a gradual reduction in seagrass resources of the Gulf of Mannar [9], the present study could identify drastic reduction in the seagrass distribution especially along the coast of the Pamban area (Chinnapalam village). It is estimated that over 152.82 ha of dense and 370.54 ha sparse seagrass bed have been lost during the four year period resulting in a net loss of over $56.08 \%$. This unusual reduction made us conduct extensive field work in this part of the Gulf which could identify the destructive process to this resource which in turn has paved the way in the reduction of the seagrass resources of this area.

The drastic reduction noticed in the seagrass resources in the present study was largely mediated by the intensive collection of the paper shell, Tellina angulata by the local fisher-women as a source of alternative livelihood income generation. The milky white shells of $T$. angulata have a good market value in the ornamental shell industry and this has induced the fisherwomen to dig out the seagrass meadows of this region on a large scale which are the habitats of this bivalve to collect the shells and thus posing a severe threat to the ecosystem (Figure 4, 5). Digging out the seagrass meadows would not only disturb the existing meadows but also would affect the further growth of seagrasses in this region, as the destructive process would fully destroy the underground rhizomes and roots of the seagrasses.

Considering the intensity of seagrass reduction, we have analyzed the 2002 satellite data to identify the rate of degradation and we found that nearly about $80 \%$ of reduction has occurred within two years (between 2002 and 2004). The field work indicates that the shell collection is gradually spreading from northeastern side of the coast to southeast. If such reduction is continued for another 10 years, we may not have the seagrass meadows at all in this part of the Gulf.

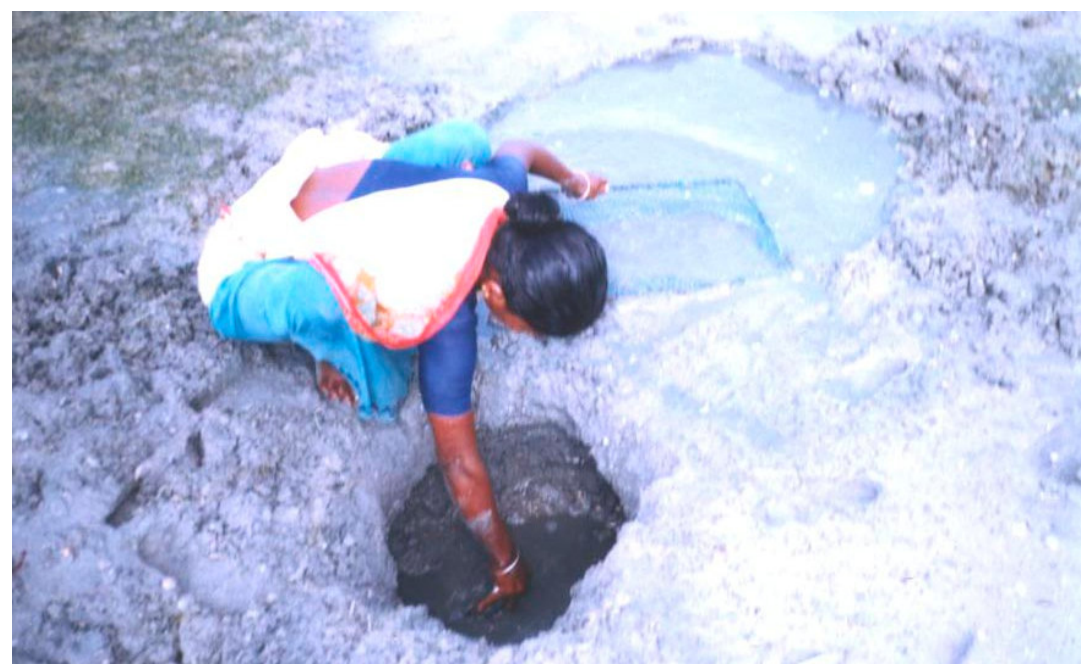

Figure 4. Deep digging of the seafloor by the fisher women for paper shell collection 


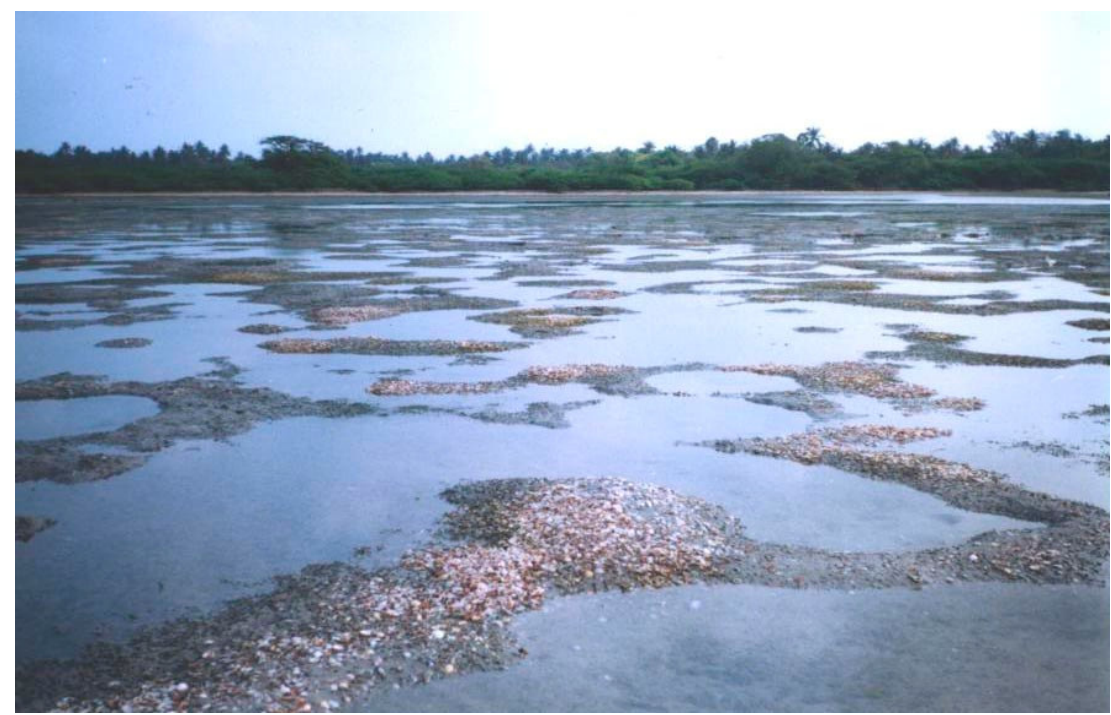

Figure 5. Seagrass beds have been disturbed and waste shells have been left out in the field

To avoid such an untoward condition in the Gulf, it is imperative to take adequate measures to conserve the seagrass resources of this region. More importantly, in the management process, it is highly essential to identify the alternative income source for the fisherwomen involved in shell collection. Introduction of sustainable seaweed collection and seaweed culture operations can be the alternative sources of income for the local fisherfolk and it would reduce the pressure on seagrasses. At the same time, it is high time to develop a National Seagrass Conservation Plan by the Government of India for implementation.

Acknowledgements Authors are thankful to the Director, CAS in Marine Biology and the authorities of the Annamalai University for providing with facilities and the Ministry of Environment and Forests, Government of India for financial support.

\section{REFERENCES}

[1] Bahuguna, A. (2002): Coastal habitat studies using RS \& GIS technology. - ISG Newsletter 9: 29-39.

[2] Bahuguna, A. and S. Nayak (1994): Mapping of the coral reefs of Tamilnadu using satellite data. - Scientific Note (SAC/RSA/RSAG/DOD-COS/SN/07/94), Space Application Centre, Ahmedabad, 56p.

[3] Bahuguna, A. and S. Nayak (1998): Coral reefs of the Indian coast. - Scientific Note (SAC/RSA/RSAG/DOD-COS/SN/16/97), Space Application Centre, Ahmedabad, 56p.

[4] Desai, P.S., A. Narain, S. Nayak, B. Manikam, S. Adiga and A.N. Nath (1991): IRS-1A applications for coastal and marine resources. - Current Science 61: 204-208.

[5] Devaraj, M. (1998): Conservation and sustainable management of the marine living resources of Gulf of Mannar Marine Biosphere Reserve. - M.S. Swaminathan Research Foundation, Chennai, $23-31$.

[6] Done, T.J. (1992): Phase shifts in coral reef communities and their ecological significance. - In: V. Jaccarini and E. Martens (eds.) The ecology of mangrove and related ecosystems, Australian Institute of Marine Science, Australia, 247: 121 - 132. 
[7] Guebas, F. D. E. Coppejans and van D. Speybroeck (1999): Remote sensing and zonation of seagrasses and algae along the Kenyan coast. - Hydrobiologia 400: 63-73.

[8] Hashim, M., R.A. Rahman, M. Muhammad and A.W. Rasid (2001): Spectral characteristics of seagrass with landsat TM in Northern Sabha coastline, Malaysia. Paper presented at the $22^{\text {nd }}$ Asian conference on remote sensing, Singapore, 1-6.

[9] ICMAM-PDa (2001), Critical habitat information system for Gulf of Mannar (India). Technical Report, ICMAM project Directorate, Department of Ocean Development, Chennai, pp. $1-88$.

[10] Jagtap, T.G. and S.N. Inamdar (1991): Mapping of seagrass meadows from the Lakshadweep Islands (India) using aerial photographs. - Journal of India Society of Remote Sensing 19: 77-81.

[11] Jagtap, T.G. (1996): Some quantitative aspects of structural components of seagrass meadows from the southeast coast of India. - Botanica Marina 39: 39-45.

[12] Mumby, P.J., E.P. Green, J.A. Edwards and C.D. Clark (2000): Remote sensing handbook for tropical coastal management. In: J.A. Edwards (ed.) Coastal Management Source books 3, UNESCO Publication, 316p.

[13] Nayak, S. and A. Bahuguna (2001): Application of remote sensing data to monitor mangroves and other coastal vegetation of India. Indian Journal of Marine Science 30: 195-213.

[14] Nayak, S., A. Bahuguna, M.G. Shaikh, R.S. Rao, C.R. Trivedi, K.N. Prasad, S.A. Kadri, P.H. Vaidya, V.B. Patel, S.H. Oza, S.S. Patel, T.A. Rao, A.N. Sherieff and PV. Suresh (1991): Manual for mapping of coastal wetland /landforms and shoreline changes using satellite data. - Technical Note (IRS-UP/SAC/MCE/TN/32/91), Space Application Centre, Ahmedabad, 63p.

[15] Nayak, S., A. Bahuguna, M.G. Shaikh and M.C. Gupta (1989): Coastal environmental studies of the Kavaratti and the Agatti coral islands. - In: Proceeding of the National Symposium on engineering applications of remote sensing and recent advances, Ahmedabad, 184-188.

[16] 1C applications for coastal zone management. - Current Science 70: 614-618.

[17] Roblee, M.B., T.R. Barber, P.R. Jr. Carlson, M.J. Durako, J.W. Fourqurean, L.K. Muchlstein, D. Porter, L.A. Yarbro, R.T. Ziemen and J.C. Zieman (1991): Mass mortality of the tropical seagrass Thalassia testudinium in Florida Bay (USA). - Marine Ecology Progress Series 71: 297-299.

[18] Thangaradjou, T. (2000): Ecobiology, culture and experimental transplantation of seagrasses of the Gulf of Mannar Biosphere Reserve (India). - Ph.D. Thesis, Centre of Advanced Study in Marine Biology, Annamalai University, India (2000) 100p.

[19] Thangaradjou, T. L. Kannan and R. Balasubramanian (2005): Seaweed harvesting as coral reef management practice - A case study on coral reefs of the Gulf of Mannar Biosphere Reserve. - In: Proceedings of the National Seminar on Rejuvenation and reclamation of coral reefs of the Gulf of Mannar, Kamaraj College, Tuticorin, 71 - 83.

[20] Thangaradjou, T., L. Kannan and S. Ravichandran (1998): Seagrasses of the Gulf of Mannar. - In: L. Kannan and R. Kannan (eds.) Living on the edge, ENVIS Publication Series 3/98, Annamalai University, $76-83$.

[21] Thanikachalam, M. S. Ramachandran (2002): Conservation of coral reefs in Gulf of Mannar: a remote sensing and GIS approach. - ISG Newsletter 9: 65-71.

[22] Thanikachalam, M. S. Ramachandran (2003): Shoreline and coral reef ecosystem changes, southeast coast of India. - Journal of Indian Society of Remote Sensing 31: 157173.

[23] Vinithkumar, N.V., S. Kumeresan, M. Manjusha and T. Balasubramanian (1999): Organic matter, nutrients and major ions in the sediments of coral reefs and seagrass beds of Gulf of Mannar biosphere reserve, southeast coast of India. Indian Journal of Marine Science 28: $383-393$. 